\title{
First report of white mould of potato caused by Sclerotinia sclerotiorum in Pakistan
}

\author{
Muhammad Waqar Alam ${ }^{1}$ (1) $\cdot$ Abdul Rehman $^{2} \cdot$ Arif Malik $^{1} \cdot$ Saira Mehboob $^{3} \cdot$ Mubeen Sarwar $^{1} \cdot$ Sher Muhammad $^{1}$
}

Received: 7 November 2020 / Accepted: 18 January 2021 / Published online: 25 January 2021

(c) Società Italiana di Patologia Vegetale (S.I.Pa.V.) 2021

Keywords Solanum tuberosum $\cdot$ Disease severity $\cdot$ Sclerotia $\cdot$ Stem rot

Potato (Solanum tuberosum L.) is one of the most widely produced and consumed vegetable in many parts of Pakistan (Majeed and Muhammad 2018). In December 2019, characteristic white mould symptoms were observed on several fields in Okara district. Diseased plants exhibited water-soaked lesions, white mycelium and large, irregular, black sclerotia (3.5-6.0 $\mathrm{mm}$ in diameter) on stems and crowns. About $23 \%$ plants were wilted and died before harvest in affected fields. The pathogen was isolated from air dried sclerotia, disinfected with $1 \% \mathrm{NaOCl}$, placed on Potato Dextrose Agar medium and stored at $20 \pm 2$ oC. Whitish cultures developed with septate and hyaline mycelia. Elliptical to globose or irregular-shaped sclerotia ( 5 to $10 \mathrm{~mm}$ diameter) were produced on the surface near the colony margin. Apothecia produced hyaline and unicellular ascospores ( 4 to $5 \times 10$ to $14 \mu \mathrm{m}$ ) on PDA after 14 days of incubation. On the basis of morphology, the fungus was tentatively identified as Sclerotinia sclerotiorum (Lib.) de Bary (Mordue and Holliday 1976). For molecular identification, genomic DNA was extracted from a representative isolate and Internal Transcribed Spacer (ITS) of the rDNA was amplified using the ITS4 and ITS5 primers (White et al. 1990). The resulting sequence (GenBank accession No. MT921621) revealed 99\% identity to sequences of S. sclerotiorum (KT595415 and MT463540) available in GenBank. The culture was deposited in First Culture Bank of Pakistan. To evaluate the pathogenicity,

Muhammad Waqar Alam

waqar.alam@imbb.uol.edu.pk

1 Institute of Molecular Biology and Biotechnology, The University of Lahore, Lahore, Pakistan

2 Department of Plant Pathology, University of Agriculture, Faisalabad 38040, Pakistan

3 Plant Pathology Research Institute, Ayub Agricultural Research Institute Faisalabad, Punjab 38000, Pakistan agar segments $\left(9 \mathrm{~mm}^{2}\right)$ from a 7-day-old culture were placed on the stems $(\mathrm{n}=10)$ of 2-month-old healthy potato plants (cv. Santa) and maintained in a greenhouse at 16 to $20{ }^{\circ} \mathrm{C}$ with $>90 \%$ relative humidity. Another 10 plants were used as controls. Five days post inoculation, all inoculated stems showed typical symptoms except controls. The fungus was reisolated consistently from symptomatic plant parts, thus completing Koch's postulates. To our knowledge, this is the first report of while mould disease on potato in Pakistan. The disease has the potential to become a serious threat to potato production. Therefore, appropriate management strategies should be adopted to avoid economic losses to farmer's community.

\section{References}

Majeed A, Muhammad Z (2018) Potato Production in Pakistan: Challenges and Prospective management strategies- A review. Pak J Bot 50(5):2077-2084

Mordue JEM, Holliday P (1976) Sclerotinia sclerotiorum. CMI Descriptions of Pathogenic Fungi and Bacteria 513. CMI, Kew, Surrey, UK

White TJ, Bruns T, Lee S, Taylor J (1990) Amplification and direct sequencing of fungal ribosomal RNA genes for phylogenetics. In: Innis MA, Gelfand DH, Sninsky JJ, White TJ (eds) In: PCR Protocols: A Guide to Methods and Applications. Academic Press, San Diego, pp 315-322 